DOI https://doi.org/10.18551/rjoas.2016-11.15

\title{
TRAINING NEEDS ANALYSIS, IMPLEMENTATION OF TRAINING, AND EVALUATION OF TRAINING TO IMPROVE HUMAN RESOURCE QUALITY: STUDY AT GUNUNG HARTA AUTOBUS COMPANY
}

\author{
Makmur M. ${ }^{*}$, Utami H.N., Wilopo W. \\ Faculty of Administrative Science, University of Brawijaya, Indonesia \\ *E-mail: makmurmunawir@yahoo.co.id
}

\begin{abstract}
In this reform era, institutions or organizations including government, state enterprises or companies, increasingly aware of how the success factors always rests on the issue of Human Resources (HR), because human resources have an important role in the development and achievement of goals, therefore it is necessary to maintenance and development. The success of human resources can be a very important concern for the company and the threat, if not accompanied by a training and control of the resource itself. This research aims to knowing training needs analysis, training implementation, and evaluation of training in the framework of improving the quality of human resources at Gunung Harta Autobus Company in Malang city. This research has shown that improving the quality of human resources in Gunung Harta which a training needs analysis/TNA that cover the needs in the level of organization, in its early stages and in the individual positions. The third analysis has been carried out properly. Evaluation result for human resource development Autobus Gunung Harta seen from written reports provided by the employees who attend training associated with their daily work. However, in the selection of employees to be included in the training and development has not systematic well because not all employees are included in the training program and the development of employee skills. In the implementation of training programs and skills development of employees PO Gunung Harta not experience significant constraints for all employees are obedient to the company's decision is responding employees for training and development as well as the presence of a coach who has been a reliable and trained in training.
\end{abstract}

\section{KEY WORDS}

Training needs analysis, implementation of training, evaluation of training.

In this reform era, institutions or organizations including government, state enterprises or companies, increasingly aware of how success factors always lies on issues of Human Resources (HR), because human resources have an important role in goals development and achievement, therefore it is necessary to maintain and further developing it. The success of human resources can be highly important for the company and becoming threat, if not accompanied by a training and control of the resource itself.

Employees was known as the main driver force regarding production process fluency within the company. This was due to no matter how sophisticated tools used by a company, it means nothing without any human to operate it. In this condition, human resources should be supplemented with sufficient education, skills and expertise so that they are capale in using and utilizing all kind of technology involved. Technology has been rapidly advancing particularly in transportation sector. Transportation advancement was due to the need for people to travel to location or other place in order to found the necessary goods or to conduct activities, and sending goods to other place in need of it (Nasution, 2008:1).

The need for transportation is equal with primary need for the people such as the need for electricity, water and other public utilities. Transportation has create and improve accessibility in economy through distribution function, either good and human distribution. And of course, all of these would be easier and faster if transportation function as it should be. 
Transportation company in order to meet the need of society member concerning transportational services, should give their best efforts in service toward service user. For service user, several factors that become their main consideration are its safety, orderly, satisfying, fast and pleasurable. High and low income of a transportation company would depend on service given toward their customers.

The need for public transportation is increasing by the year but government as service operator toward the society were not able to meet the need of public transportation. The government has already give their effort to meet the need of society members by establishing a state company as limited liability company called Damri, which until now still consistent in running the task as one of the service provider for human and goods transportation by using buses and trucks. But to meet the need of today it would be insufficient to rely only on Damri buses. In transportation facilities provision, government has create a space for private party to serve the people, lots of private party start to developed nowadays. The same can be said for public bus transportation. At this moment, not much people would like to go out of town, either in rural areas or provincial areas for their own needs. Based on survey in 10 cities, there were 26 PO AKAP who operate in East Java but mostly focused on middle to high class by providing service in Executive/VIP class, while only small part of it operated in Business AC and Super Executive.

By looking at the development of Autobus Company in Eas Java province, government has given private party to give public transportation service for the people. One of them is Autobus Company (PO) Gunung Harta. PO Gunung Harta is one of the companies that works in transportation service inter-city and inter-provincial areas (AKAP) also for tourism. As we all know, at this moment there were lots of autobus company that compete to one another to give luxurious facility with the intention to improve service and company image in order to gain trust of their customer. PO Gunung Harta is one of them who always fix and improve services and facilities of its bus armada.

Although there were lots of autobus companies particularly in East Java Province, it didn't warranty that human resources quality within those companies would be good enough. Lots of complains has been filed by member of society particularly from bus passengers. For example, driver action that drive their vehicle in dangerous manner, didn't provide comfort and safety for its passengers. These dangerous driver would be influenced by several factors. It might be due to driver's unhealthy condition such as illness, fatique, running out of time, and also might be due to their obligation to accomplish target and others thus it would affect the way they drive and may causing traffic accidents where passenger become the victim.

Skill and awareness possessed by public transportation driver has fairly contributed toward safety aspect, comfortness and traffict fluency in general. Furthermore, driver also might do traffic violation, such as stopping vehicles in sudden ways without giving any sign, stopping vehicles for loading or discharging passengers not in their appropriate place and or stopping not in its predetermined site such as bus stop, terminal, stopping or resting near traffic light.

Dangerous driving by bus driver usually concern with pay or wage system. Driver would drive dangerously for more money and would likely racing with other driver without considering their passenger's safety. With target system, crew would not possess any money and they should look for passengers on their own, therefore driver would try to get as many passengers as possible so that they would earn the surplus money after target has been achieved. Impact of this kind of system would apparent in its bus armada, since driver would drive as he please. Other wage system that might by used by autobus company is premi system.

With premi system, normally fuel would be paid by the company, wage system would be based on percentage from all revenue produced by public transportation in question. Impact entail of this system is driver would like to accelerate more than necessary thus bus would easily degraded but passengers would feel satisfied since bus is fast and able to reach their destination in short amount of time. This would cause some passenger to choose other alternative in public transportation. Transportation that felt more comfortable, effective, and 
efficient although it cost more. For more revenue, driver would be facing public transportation issues and some might end up in tragic traffic accident, as often happen in East Java.

Based on preliminary interview, in Gunung Harta autobus company, issues faced would be high employees turnover and lack of crew sufficiency also some of driver that drive dangerously and didn't consider their passenger's comfort. Lots of traffic violation were done and they would avoid the responsibility thus it is quite difficult to tied them up. Regarding this matter, training is necessary in order to improve human resources quality in Gunung Harta autobus company in Malang city.

Through training, it is expected that company resources would developed. By training, employees could develop their ability and skill and made it their capital to improve their work achievement.

Based on the above description, study with the title: «Training needs analysis, implementation of training and evaluation of training in order to improve human resources quality» (Study at Gunung Harga Autobus Company in Malang city) is necessary to be conducted.

Problem Formulation. This paper wants to seek the answers to the following questions:

1. How does training needs analysis able to improve human resources quality in Gunung Harta autobus company in Malang city?

2. How does training implementation conducted by Gunung Harta autobus company?

3. How does training evaluation conducted by Gunung Harta autobus company in Malang city?

4. What are impeding factors to conduct training in order to improve human resources quality in Gunung Harta autobus company in Malang city?

\section{LITERATURE REVIEW}

Training Needs Analysis (TNA) is a phase done before training and is an inherent part in planning training to gain comprehensive description regarding material, time alocation for each material, and appropriate learning strategy to be used in implementation of training to make it beneficial for training participants.

Therefore, generally speaking, it can be said that Training Needs Analysis is a determination of difference between actual condition and what should be in human work within an organization or group of organization regarding definition, knowledge, skills and attitude.

Goldstein and Bukton (Mangkunegara, 2001) suggest, needs determination regarding training should be done through analysis in organization, position/title/task, or individual level.

1. Training Needs in Organizational Level:

Training Needs in Organizational Level is set of general data from part or division that in needs of training.

2. Training Needs in Occupational Level:

Existence of KSA (knowledge, skill, attitude) gap is needed to accomplishing work with either periodical or incidental nature. Training needs in occupational level can be discovered by using mission, function, task and sub-task analysis which outlined into competences. Afterward, these competences could be categorized as such so that producing training standard for each position.

3. Training Needs in Individual Level:

Regarding with who and what kind of training needed, training needs in individual level can be compiled using TNA Tool (Training Needs Assessment), which are by comparing competence standard gap in particular position with competence possess by employees in the position in question.

Implementation originated from verb «implement» in English and become noun «implementation» which carry the meaning conducting or executing something predetermined or pre-planned. Thus, implementation is an effort to operationalize predetermined plans or programs. 
Table 1 - Previous Research

\begin{tabular}{|c|c|c|c|}
\hline No. & Author & Title & Summary \\
\hline 1. & $\begin{array}{l}\text { Ramadhan } \\
\text { (2008) }\end{array}$ & $\begin{array}{l}\text { Training Needs Analysis for } \\
\text { Employees in Seismic Data } \\
\text { Acquisition (SDA) Department } \\
\text { of PT Elnusa Geosains }\end{array}$ & $\begin{array}{l}\text { Training needs analysis using TNA-T method, } \\
\text { current condition of employees showed that there } \\
\text { was gap between actual ability and expected ability } \\
\text { thus training is necessary. }\end{array}$ \\
\hline 2. & Putri (2005) & $\begin{array}{l}\text { Training Needs Analysis for } \\
\text { administration employees in PT } \\
\text { Indonesia Power UBP Saguling } \\
\text { Cimahi }\end{array}$ & $\begin{array}{l}\text { Training needs done toward five type of ability as } \\
\text { study subject has showed that administration } \\
\text { employees in PT. Indonesia Power Saguling still } \\
\text { need training and implementation of training program } \\
\text { by the company still not yet effective in improving job } \\
\text { ability of its employees, since there was still gap in its } \\
\text { employee's actual ability and work ability determined } \\
\text { by the company. }\end{array}$ \\
\hline 3. & $\begin{array}{l}\text { M. Irawan } \\
\text { Fazurachman } \\
\text { Balikpapan city }\end{array}$ & $\begin{array}{l}\text { Improvement of Local Civil } \\
\text { Service Resources } \\
\text { Development through } \\
\text { Education and Training in } \\
\text { Balikpapan city }\end{array}$ & $\begin{array}{l}\text { (1) Civil service resources in Balikpapan city has } \\
\text { considerable potential but not yet empowered in } \\
\text { optimum manner; (2) forms of civil service resources } \\
\text { development done by Balikpapan city government } \\
\text { was through (a) structural training, (b) functional } \\
\text { training; ( } 3 \text { ) civil service resources development, as } \\
\text { follows: (a) through administration selection process } \\
\text { and (b) through written selection test also interview. } \\
\text { If they passed this process, they would participate in } \\
\text { ADUM education and training; (4) education and } \\
\text { training in creating professional civil service in } \\
\text { accordance with principle the right man on the right } \\
\text { place and facilities still insufficiently adequate. }\end{array}$ \\
\hline 4. & $\begin{array}{l}\text { Cahkung (2005) } \\
\text { Palangkaraya } \\
\text { city }\end{array}$ & $\begin{array}{l}\text { Development of Civil Service } \\
\text { resources through education } \\
\text { and leadership training level IV } \\
\text { in order to improve work } \\
\text { achievement (Study at Regional } \\
\text { Secretariate Environment of } \\
\text { Palangkaraya city) }\end{array}$ & $\begin{array}{l}\text { Based on the conclusion, civil service development } \\
\text { and education also training was not yet perfect. This } \\
\text { was exarcebated by poor ability of instructor and } \\
\text { less systematic education and training method, thus } \\
\text { its result is hard to measure. Meanwhile, on the } \\
\text { other side, work of civil service was still lacking, and } \\
\text { as its consequence, work error would often occurs. }\end{array}$ \\
\hline 5. & $\begin{array}{l}\text { Syamsuddin } \\
\text { Maldun (2015) } \\
\text { Makassar city }\end{array}$ & $\begin{array}{l}\text { Policy Development Training } \\
\text { And Education Resources To } \\
\text { Reform The Local government } \\
\text { District Of Makassar sidenreng } \\
\text { rappang }\end{array}$ & $\begin{array}{l}\text { Analysis result in policy development over education } \\
\text { and training should be based on competence as it } \\
\text { was expected to become the trigger for civil service } \\
\text { in delivering good service. Civil service competence } \\
\text { was directly helpful in accomplishing task on the } \\
\text { office. Strategy to improve competence reform } \\
\text { through education and training should not be seen } \\
\text { as in partial but in holistic manner. In overall } \\
\text { regarding this item, there should be creation to } \\
\text { manage the system, implementing system in } \\
\text { consistent manner, and continuous improvement for } \\
\text { the existing system in order to create professional } \\
\text { civil service resources. }\end{array}$ \\
\hline
\end{tabular}

According to Conyers and Hills (1990, p. 154) implementation refers to all translation process for vast policy objective or objectives with apparent result in specific projects or program. While Presmann and Wildavsky (1973, in Conyers and Hills, 1990, p. 155) define implementation as interactional process between goal determination and act directed to achieve those goals.

Based on the above explanation, implementation is a continuation process after plan determination was accomplished. By implementation, goals of a program that has been determined in planning would be applied thus eventually it could be known whether a program being run has able to achieve program's goals and target as expected during plan formulation. Furthermore, it would also discover factors that influencing its success and failure of implementation. These factors should become the guidance or reference for program implementatoin, thus implementation could succeed in accomplishing target as expected. 
According to Sikula in Mangkunegara (2009:44) he suggest that training is a shortcourse education process which use systematic and organized procedures for non managerial employees to learn the knowledge and technical skill in limited purpose.

Simamora (2006:273) argue that training is a learning process which involve skill, concept, rules or attitude acquirement to improve employees performance. Along with this opinion, Handoko (2010:104) suggest that training was meant to fix mastery of several skills and certain, detailed and routine work implementation technique.

According to Mangkuprawira (2002:122) training is a process that teach knowledge and certain skill also attitude so that employees can become more skillfull and able to do his job better and in accordance to the valid standard.

Mathis and Jackson (2002:5) argue that training is a process where people would reach certain ability in order to help in accomplishing organization goals. Davis and Werther in Sedarmayanti $(2010 ;: 164)$ stated that training prepares people to do their present job and development prepares employees needed knowledge, skill and attitude. It means that training would prepare people in doing their job and development to prepare employees that need knowledge, skill and attitude.

According to Gomes (2000:120) training is an effort to fix employees performance in certain job that become his/her responsibility, or a task related with his/her job. To become effective, training usually consists of learning experience, planned activities and designed as answers or identified needs.

While according to Ford et al. (1994:31) training is effort by organization that deliberately done to improve current performance and future performance by increasing ability.

Training is part of an education process with the objective to improve certain ability or skill of someone or a group of people (Notoadmojo, 1998:178). Moreover, Edwin B. Flippo as quoted by Moekijat (1984:1) reveal that training is an act to improve knowledge and skill of an employees in doing certain job. Nitisemo (1996:53) formulated training as an activity which meant to fix and develop attitude, skill and knowledge from its employees and in accord with company's wants. According to Tayibnapis (1995:195) training is a media to improve insight and skill which was done in short time where skill aspect has more prevalence.

Training according to Simamora $(2006: 342)$ is a systematic process in changing behavior of employees toward particular direction as an effort to improve organizational goals. In training, environment was created whereas employees could obtain or learn about specific attitude, ability, skill, knowledge and behavior which related with the job.

According to Siagian (1988:175) definition of training is teaching process by using certain technique and method conceptionally and it can be said that exercise was meant to improve skill and ability of someone or a group of people. Normally it works on an organization with efficiency, effectiveness and work performance that could be improve in directed and pragmatic manner. Handoko (1998:104) emphasize clearly enough that training was meant to fix mastery of several skill and technique of certain job. It was detailed, routine and also prepares employees to conduct their current function.

In the same line, Tulus (1982:89) suggest that training is a short term education process for operational employees to obtain operational technique skill in systemtic way. The same goes with Edwin B. Flippo as quoted by Moekijat $(1991,4)$ that says training as follows: training is necessary to help employees improve their skill and knowledge related with task done in his/her workplace.

Objectives of training according to Moekijat (2003) were:

1. To develop skill thus any task can be accomplished faster and in effective manner;

2. To develop knowledge, thus any task can be accomplished rationally;

3. To develop attitude, thus it would raise cooperation willingness with peers and superior.

According to Handoko (1994:112) there were two main categories of training program which are «on the job training and off the job training»: 
On the job training. This is training method whereas employees being trained about new task with direct supervision of an experienced instructor (usually by other employees). Technique usually used in practice would be:

1. Positional rotation;

2. Job instruction training;

3. Apprenticeship;

4. Counseling;

5. Temporary assignment (Handoko, 1994:112).

More clearly, those method would be described below:

1. Positional rotation: employees would be given knowledge about different division in practice with many kind of managerial skill.

2. Job instruction training: clues concerning job was given directly on the job and used particularly to train employees regarding implementation of their current work.

3. Apprenticeship: It is a process of learning from one or several other with more experience.

4. Counseling: superior would give guidance and directive toward employees in implementing their routine work.

5. Temporary assignment: assigning employees in certain managerial position for certain period of time. Employees would involved in decision making and problem solving of real operational issues.

Off the job training. This is training method implemented in separate location from the job and conducted in different time from regular working hours. Handoko (1994:114) suggest that «off the job training method consist of simulation and information presentation techniques». More description about it was given below:

1. Information Presentation Technique. Information Presentation Technique is how to present information with the purpose to introduce new knowledge, attitude and skill toward participans. This technique consist of:

a. Regular course;

b. Discussion technique;

c. Group discussion;

d. Behavior modeling technique;

e. Apprenticeship technique was done by sending employees from one organization toward other institution or other organization.

2. Simulation Technique.

To find out about success in education and training, there should be evaluation. Activities in evaluation consist of collecting information regarding changes as the impact or due to training. Kirkpatrick (in Moekijat, 1993:47) divide training assessment area into four different level which are «reaction level, learning level, behavior on the job level and outcome level». For more description, see explanation below:

a. Opinion/thinking pattern level. On this level, what we want to know is reaction effect toward training program composition such as target, policy, procedure, method, curriculum, instructor, participant and implementation time. In other word, evaluation purpose in this reaction level is for program improvement.

b. Learning level. On this level what we would like to know is what is the effect of training program toward learning result of participants. In other words, evaluation purpose in this learning level is to improve knowledge, skill and attitude of participant in classroom.

c. Behavior on the job level. On this level we would like to know what is the effect of material taught toward behavior on the job, in other word, evaluation in this level is to improve behavior on the job thus knowing behavioral change of before and after training was commenced.

d. Outcome level. On this level we would like to know the effect of implementation in workplace toward organization activities. In other word, evaluation purpose concern with improving service, improving productivity and better work quality and discipline. 
Human resources management is part of management that focusing its discussion in systematization of human role to realize optimum objectives. According to Nitisemo (1996:11) personnel management (human resources management) is a discipline and art to implement planning, organizing, actuating and controlling, therefore effectiveness and efficiency of personnel management could be improve as much as possible in order to attain objectives.

Dessler (2008:5) human resources management is the process to obtain, train, assess, and giving compensation toward employees, paying attention toward their work relations, health, safety, and fairness issues.

Malaju SP Hasibuan as quoted by Sudalduri in Cahyono (1994:4) stated that human resources management is a discipline and art that regulate relations and role of labor, to be effective and efficient in accomplishing organization, employees and society's objectives. Human resources management function according to him consist of planning, organizing, directive, controlling, provision, development, compensation, integrating, maintenance, discipline/sanction and dismissal.

\section{METHODS OF RESEARCH}

In this study, author would like to obtain description about training needs analysis, training implementation and training evaluation in order to improve human resources quality of Gunung Harta autobus company in Malang city.

This study aims to dissect meaning behind an event or phenomenon by giving basic explanation or understanding based on rational reasons. With this basis, this study was categorized into qualitative study (Islamy, 2001:24). Focus of this study concerns:

1. Training Needs Assessment in order to improve human resources quality in Gunung Harta autobus company in Malang city, East Java province consist of:
a. Organizational needs;
b. Occupational needs;
c. Individual needs.

2. Training implementation in order to improve human resources quality consist of:
a. On the job training;
b. Off the job training.

3. Training evaluation in order to improve human resources quality consist of:
a. Opinion evaluation;
b. Learning criteria evaluation;
c. Behavioral evaluation;
d. Outcome evaluation.

4. There were factors impeding training in order to improve human resources quality. According to Hasibuan (2006:85-86), developmental obstacles which could impede implementation of education and training are:
a. Participant;
b. Instructor;
c. Development facilities.

This study was conducted in Malang city, East Java Province with snowball sampling technique. Data used in this study is primary and secondary data also using interview as its data collection technique. Key informant in this study is Head of Personnel Division in Gunung Harta autobus company, Head of Tourism Division, Operational Staff, ticketing employees, drivers and mechanics of Gunung Harta autobus company. Data was analyzed using interactive model data analysis developed by Miles, Huberman and Saldana (2014). This study was done in interactive manner and continuous in nature until it reach saturated point. Saturated point means data can be divided then combined together into one beneficial finding and able to be used by others. Processes in this study is taking cycle form which covers data collection, data display, and conclusion drawing or verification. 


\section{RESULT AND DISCUSSION}

Analysis in Improving Human Resources Quality in Gunung Harta autobus company in Malang city, East Java Province. One of important resources in management is human resources. The importance of human resources should be consciously known by all management level without considering technology advancement. Human factor still hold an important role for organization success.

Needs analysis in Gunung Harta autobus company in Malang city is incidental in nature, since all decision either concerning mechanic training in new unit provision or seminar provision by ticketing employees regarding service procedures toward passengers/consumers by the company is not programmed in written form. Based on this, the needs in organization level of Gunung Harta autobus company has already in accord with suggestion from Rudi J. Utomo (in Cahyono, 1999:81) which stated that «Organizational needs would need a person who was capable in implementing predetermined task according to occupational requirement, in order to becoming capable in implementing the occupational position employees would need to obtain knowledge and skill about how to conduct their duties».

With the existence of training, employee's knowledge regarding his/her duties would increase. Employees would always work well. And vision mission of Gunung Harta autobus company would be accomplished.

Therefore, improving human resources in Gunung Harta autobus company in Malang city is a developmental effort with integral nature either regarding human resources as individual and as system (organization as human resources containment) to meet its needs.

Changing in company status into liability company in 2013 has raise the awareness of Gunung Harta autobus company concerning the importance of human resources quality improvement. Gunung Harta autobus company would need employees with high quality and high performance. To obtain skillfull employees, they need to conduct training since training is an effort to prepare high quality employees in aid to grow and develop organizational purposes along with development of current knowledge and technology. Strategy in human resources improvement quality done by Gunung Harta autobus company is by giving work motivation toward their employees. When there was increase in works, employees was given assignment to participate in training and if their performance improved after participating in a training, employees would earn their bonus.

To manage resources, it is necessary to compile organization personnel, to motivate employees, to lead employees, to communicate with employees, to arrange work group and to evaluate their performance which was known as management function (Royat, 1994). Strategic human resources management is the key for the company to obtain sustainable competitive by integrating its human resources management with its business strategy. Competence improvement in the company particularly in human resources is the main element to achieve success for the company and human resources involvement within development and implementation of business strategy would create organizational effectiveness in its industry (Karami, 2001).

Gunung Harta autobus company give their employees a change and also provide facilities to improve their knowledge, skill, behavior, insight, managerial capability and leadership through training program and skill development either inside the company or outside the company. According to Werther and Davis (1989:270) human resources development or individual career development was started from individual characteristic, thus each person would responsible over its own career development. Job and organizational characteristic would also determine individual career development such as less encouraging leadership toward subordinate, poor employees relationship and less possible working condition would highly impeding human resources development. In formal kind, human resources development was done through training, while in informal kind, it might be seen from one working experience.

Human resources quality improvement has been sufficiently done by Gunung Harta autobus company in Malang city. It was preceeded by needs analysis, but its developmental 
program that contain routine technical nature would still waiting for one being held by Pusat Pelatihan (PUSDIKLAT) IPOMI and Ministry of Transportation.

Based on interview result between author and management of Gunung Harta autobus company, we obtain information that strategy of Gunung Harta autobus company in improving its human resources quality was done through two line, which are:

Training Needs Analysis (TNA - Training Needs Assessment) in order to Improve Human Resources Quality in Gunung Harta autobus company in Malang city, East Java Province. Training needs analysis is a step done before conduct training and was an integral part to design training in order to obtain comprehensive picture regarding material, time allocation for each material and learning strategy that should be implemented in hosting training so that training would be beneficial for training participant.

Based on this analysis, it would be discovered what kind of training is relevant for an organization currently and also in future time. Organization cannot determine their training as they please without analyzing the needs and purpose/aims to be accomplished. Those who conduct Training Needs Analysis program usually were training designers in order to collect information regarding training needs that would be used as consideration basis to compile training design. Based on results in training needs analysis in Gunung Harta autobus company, it is known that training needs analysis implemented by this company is already in accord with Goldstein and Bukton theory. Mangkunegara (2001) suggest that needs determination for training should be done through analysis either in organization level, occupational/task/work, or individual level:

1. Training needs in organizational level:

Training Needs in Organizational Level is set of general data from part or division that in needs of training.

2. Training needs in occupational level:

Existence of KSA (knowledge, skill, attitude) gap is needed to accomplishing work with either periodical or incidental nature. Training needs in occupational level can be discovered by using mission, function, task and sub-task analysis which outlined into competences. Afterward, these competences could be categorized as such so that producing training standard for each position.

3. Training needs in individual level:

Regarding with who and what kind of training needed, training needs in individual level can be compiled using TNA Tool (Training Needs Assessment), which are by comparing competence standard gap in particular position with competence possess by employees in the position in question.

All training activities held by Gunung Harta autobus company is already in line with superior directive in determining company's training needs, in occupational and individual level. Existence of training analysis held by Gunung Harta autobus company would brought benefit in improving employees performance, that are:

a. Improving satisfaction and encouraging working spirit also self confidence of employees

b. Improving working method and system thus it would accelerate working process and time efficiency

c. Reducing mistakes in working thus reducing wastefulness

d. Improve communication and cooperation between employees to create good and comfortable working environment.

Implementation of Training in order to Improve Human Resources Quality. After looking at the importance of employee's performance in accomplishing company objective, Gunung Harta autobus company try to improve its human resources quality by holding training program. Training program held by Gunung Harta autobus company was initiated through guiding new employees concerning issues regarding bus ticket or training concerning new bus unit. According to Siagian (1988:175), definition of training is a teaching process with certain technique and method and conceptionally could be said that training was meant to improve skill and working ability of someone or a group of person. Normally it was targeted to those who already works in an organization whereas its work efficiency, effectiveness and 
productivity could be improved in directive and pragmatic manner. Training method given toward employees has already in line with theory suggested by Siagian that is concerning two main categories of training and educational program which are practical method (on the job training) and information presentation techniques (off the job training). Method implemented by company in order to improve its human resources quality has already in line with the theory, thus its implementation was considered sufficient and adequate.

In implementing training program and skill development, Gunung Harta autobus company used training techniques includes:

1. Training and development of On The Job Training. On the job training is training held by Gunung Harta autobus company and implemented as part of employee's work activity. On the job training was taking forms such as:

a. Understudy or coaching

Gunung Harta autobus company conduct guidance over job done by its employees. This work guidance for one employees in one division to other division was done to help employees if there is something that he/she doesn't understand. Coaching or guiding would be very important since it would brought better communication between employee's level within the company in looking for solution appropriate for issues being faced.

With guidance, employees would be able to learn about more productive behavior pattern. In this case, manager would hold important role in adaptation process and new employee's ability in working according to the company's needs.

b. Apprenticeship

Gunung Harta autobus company conduct apprenticeship program by approving employees for apprenticeship in Gunung Harta with expectation that after completing apprenticeship, this employee candidate would be recruited by the company considering his/her productivity. Situation in employees environment would be different, thus employee would be skilled in facing new issues. This apprenticeship can be used as try out before employees was stationed into new position.

2. Training and developoment of Off The Job Training.

Skill development for employees in Gunung Harta autobus company was done by the company itself and sometimes working together with other parties. This training was done from time to time in accord with company's and employee's needs. Several training done by Gunung Harta autobus company includes:

a. IPOMI Training:

IPOMI specifically contain young generation of bus entrepreneur, those who would like to comprehend and share in running bus venture. With the existence of this association, service for member of society can become better.

IPOMI held special training for driver and working together with DODIKLATPUR in Klaten. This training was held to improve driver's mental as land transportation service agent so that driver would posses high self-discipline and knowing their own personality thus they would not become an arrogant driver toward their passengers, and comply company and traffic regulation. It was also expected that drivers involved in this training would become discipline driver. Thus their company would become better in its service and safety aspect.

In training held by DODIKLATPUR Klaten, participant was trained hard such in military training. They were prepared in physical and spiritual in order to become good service provider for the people and the company. Their character was build so that their dangerous driving habit would be change into the better.

Training held by IPOMI for three days was aimed to trained drivers with discipline regarding their task as driver. Material speaker would consist of those from military, police department, Transportation Agency, and also from IPOMI management which no less were those driver's superior. National insight, patriotism, vehicle control from IPOMI, and supplementary knowledge concerning vehicle's lubricating oil, and operational briefing regarding vehicle's AC.

It is expected that government would build driver school to educate driver so that they comprehend their task and responsibility in operating bus. Safety issues cannot be taken for granted. Especially when government has promoting safety action decade on the road. 
b. AKUT Training from Transportation Ministry:

Activities related with guidance for drivers is one of the government's responsibility, either central government or regional government. This responsibility was realized in commencement of AKUT selection, either in district/city level, provincial level and national level.

Related with this, as responsibility of central government toward regional government, since 2010 monitoring activity regarding Implementatoin of AKUT selection was held in several province. This monitoring activity was aimed to obtain implementation description of AKUT in regional area and to give solution if there were obstacles during implementation. In conducting AKUT activity which run for years until now, government continuously conduct evaluation and improvement in its implementation thus it is expected that result of this activities would give more added value.

Therefore, in AKUT selection of national level, Training in Emergency Handling (PPGD - Pelatihan Penanganan Kegawatdaruratan) from Indonesian Red Cross (PMI) also Socialization of Drug Abuse from National Narcotics Agency (BNN) as a new material given to fulfill the need of driver in accordance with current issues.

AKUT selection in national level was followed by participant from all type of public transportation drivers, consist of public cars (Angkot), AKAP, AKDP, taxies, travels and tourism. This year, AKUT selection in national level was followed by 56 participants that comes from 29 provinces. From 33 provinces, 4 provinces announce that they would not participate on it, those are: Southeast Sulawesi, Papua, West Papua and Bengkulu Provinces.

Assessment coverage would consist of attitude, knowledge, and skill with emphasize on attitude. Other than these three, health test result would also become one consideration in determining final grade for all participants. Assessment material tested in this AKUT selection would consist of: Traffic Knowledge and Road Transportation, Knowledge in Insurance, Defensive Driving (theoretical test), outbond, disciplinary activities, attitude and behavior, also group dynamics. Assessment would be done by panelist consist of several official from institution such as: KTD Directorate, BSTP Directorate, PP. IMI, PT. Jasa Raharja (persero), Motivator (PT. Credo), Korlantas Mabes Polri and Rindam Jaya.

c. Training in Panin Bank:

In conducting training, Gunung Harta autobus company would cooperate with Panin Bank to improve its human resources quality. This training would related with good communication procedure toward consumers.

Training Evaluation in order to Improve Human Resources Quality in Gunung Harta autobus company in Malang city, East Java Province. To assess the programs conducted by Gunung Harta autobus company in order to improve employee's skill through training and skill development, evaluation was held to determine whether those predetermined targets has already accomplished or not.

In Gunung Harta autobus company, evaluation was done in progress, it means that assessment was done after employees participating in training and skill development whereas they have to give written report to the company. This report would contain employee's performance report regarding knowledge possessed from training and skill development. Report received by the company from the employee who participate in training and skill development would always been checked in order to found out his improvement. For those who had ability improvement and willing to teach others about it would receive reward from the company, in the form of bonus. According to Kirkpatrick (in Moekijat, 1993:47), to found out training success there should be evaluation. Activities in evaluating training should be take form of information collection regarding the change as the impact of training.

Based on evaluation result held by Gunung Harta, after participating in quality training their employees has showed improvement in their thinking pattern, their knowledge and skill, their attitude and productivity. Success of these training has able to influence human resources quality which is marked by improvemen in revenue due to ticket sold in Gunung Harta that shown in table below. 
Table 1 - Data of ticket sold in Gunung Harta autobus company from 2012-2015

\begin{tabular}{|l|l|l|l|l|l|l|}
\hline \multicolumn{1}{|c|}{ Designated Route } & \multicolumn{1}{|c|}{2013} & \multicolumn{1}{|c|}{2014} & \multicolumn{1}{c|}{2015} & \multicolumn{1}{c|}{2013} & \multicolumn{1}{c|}{2014} & \multicolumn{1}{c|}{2015} \\
\hline Malang-Denpasar & 4.699 .887 .760 & 4.278 .500 .250 & 4.128 .954 .500 & $26,59 \%$ & $22,53 \%$ & $17,60 \%$ \\
\hline Malang-Jakarta & 4.989 .530 .200 & 6.410 .098 .000 & 6.339 .186 .700 & $28,23 \%$ & $33,75 \%$ & $27,02 \%$ \\
\hline Tulungagung-Jakarta & 1.128 .740 .200 & 1.259 .096 .000 & 1.934 .339 .000 & $6,39 \%$ & $6,63 \%$ & $8,25 \%$ \\
\hline Ponorogo-Jakarta & 6.853 .952 .600 & 6.962 .310 .000 & 8.338 .044 .000 & $38,78 \%$ & $36,66 \%$ & $35,54 \%$ \\
\hline Malang-Purwokerto & - & & 68.581 .600 & & $0,00 \%$ & $0,29 \%$ \\
\hline Banyuwangi-Jakarta & - & 80.395 .000 & 2.648 .833 .550 & & $0,42 \%$ & $11,29 \%$ \\
\hline Amount & 17.672 .110 .760 & 18.990 .399 .250 & 23.457 .939 .350 & & $7,46 \%$ & $23,53 \%$ \\
\hline
\end{tabular}

Source: Gunung Harta autobus company in Malang city, 2016.

Based on the above table, AKAP ticket sold between 2013-2015 could be seen increasing from year to year. In 2013, amount of ticket sold was Rp 17.672.110.760,- which increase in 2014 with ticket sold 7,46\% more and becoming about Rp. 18.990.399.250,while in 2015 this amount increase 23,53\% more and becoming Rp. 23.457.939.350,-.

Impeding factors in conduct training to improve human resources quality in Gunung Harta autobus company in Malang city, East Java province. According to Hasibuan (2006:8586), obstacles in development that could impede training implementation, such as:participant, instructors, and development facilities. But based on result study on the field it was found out that these factors was not in line with those mentioned by Hasibuan (2006:8586). All training participant is very enthusiastic in taking part during training. There was nothing problematic occurs from participant element. This was due to good motivation of each participant. It was compulsory for all employees in Gunung Harta autobus company to involved in training held by the company or those held outside the company.

Instructor or trainer in development effort held by Gunung Harta autobus company is person or a group of person that give education toward employees in Gunung Harta autobus company either managerial or operational employees. Instructor has a very important role in improving employee's performance through training and skill development held by the company. In training and skill development held by Gunung Harta autobus company, they use trainer or instructor from within the company, outside the companya and combination of both. These variation was done in accordance with company's and employees needs him/herself:

a. Instructor from within the company. Manager or head of division to become internal instructor from inside the company. Manager has responsibility to give training toward employees under his supervision by giving clues and direction in accomplishing task. Manager should also teach how to operate tools, machinery and others.

b. Instructor from outside the company. Instructor in training and skill development was invited from the outside of Gunung Harta autobus company in order to give new knowledge. Gunung Harta autobus company was working together with Transportation Ministry and Indonesia Young Autobus Entrepreneur Association (Ikatan Pengusaha Otobis Muda Indonesia - IPOMI) for their employees. For training and skill development in managerial aspect, Gunung Harta autobus company and Transportation Ministry also IPOMI has good cooperation to improve employee's skill thus it would increase their job performance.

\section{CONCLUSIONS AND SUGGESTIONS}

Based on author's observation in Gunung Harta autobus company in Malang city, human resources quality improvement in Gunung Harta autobus company was based on training needs analysis (TNA) which encompass needs in organization level, in occupational level and in individual level. Those three analysis has been well implemented.

Training implementation in Gunung Harta autobus company in Malang city with its training method either on the job training or off the job training was already well implemented. But in its provision, they still wait for cooperation with other institution. 
Evaluation toward result of human resources improvement in Gunung Harta autobus company can be seen from written report by employees who participate in training relative with his/her routine task on the job. However, in selecting employees to participate in training and skill development, it was not yet systemized since not all employees was able to participate in training and skill development program.

In implementation of training and skill development program, employees of Gunung Harta autobus company did not experience any meaningful obstacle since all employees comply to company's decision. Employees has good response toward training and skill development program, it was also because the existence of reliable and skilled instructor in handle the training. Based on the above conclusions, Training Needs Analysis, Implementation of Training and Evaluation of Training in order to Improve Human Resource Quality has been well implemented, but there should be improvement in better selection system for employees who participate in training so that this program was able to gain maximum result in all aspects.

Authors would like to propose several suggestion that could become consideration material for Gunung Harta autobus company in Malang city in providing training and skill development program for their employees, such as:

1. In order that employees who participate in training could give maximum response and follow up, they should be giving training and skill development in accord with their job description.

2. Better system in selecting employees to participate in training and skill development program should be used, such as by using seniority principle in accordance with their work tenure.

3. Gunung Harta autobus company should improve its human resource quality by provide training in long term so that predetermined goals of the company could be accomplished and raise a better service in the future.

4. Evaluation toward training implementation result should continuously improved so that superior could assess whether implementation system of this training has already succeed or not.

\section{REFERENCES}

1. Conyers, Diana dan Peter Hills. 1990. An Introduction to Development Planning in The Third World. John Wiley \& Son)

2. Dessler Gary, 2008. Manajemen Sumber Daya Manusia, Edisi Kesepuluh Jilid I, Indeks Jakarta. Dialihbahasakan oleh Tri Wibowo Budi Santoso. Jakarta: Kencana.

3. Ford, J.K., et.al. 1994. Improving Training Effektiveness in Work Organization, Hillsdale, New Jersey.

4. Gomes, Faustino Cardoso, 2000, Manajemen Sumber daya Manusia, Yogyakarta, Andi. Group.

5. Handoko, T Hani. 1996. Manajemen Personalia Sumber Daya Manusia. BPFE. Yogyakarta.

6. Handoko, T. Hani 2008, Manajemen Personalia dan Manahjemen Sumber Daya Manusia, edisi kedua, cetakan keenambelas, penerbit : BPFE, Yogyakarta.

7. Hasibuan, Melayu Sp. 2000. Manajemen Sumber Daya Manusia, Edisi Revisi, Bumi Aksara, Jakarta

8. Islamy, M. Irfan, 2001, Prinsip-prinsip Perumusan kebijakan Negara, Bumi Aksara, Jakarta.

9. Karami, A., Analoui, F \& Cusworth, J. (2004). Strategic Human Resources Management and Resource-Based Approach: The Evidence from the British Manufacturing Industry. Management Research News.

10. Mangkunegara Anwar Prabu, 2005. Evaluasi Kinerja Sumber Daya Manusia. Refika Aditama, Bandung.

11. Mangkunegara, A. A. Anwar Prabu, 2008, Manajemen Sumber Daya Manusia Perusahaan. Bandung : PT. Remaja Rosdakarya. 
12. Mangkunegara, A. A. Anwar Prabu. 2006. Perencanaan dan Pengembangan SDM. Bandung: Refika Aditama.

13. Mathis L Robert, John.H. Jackson. 2002. Sumber Daya Manusia. Jakarta : PT. Salemba Empat.

14. Miles, Matthew B \& A.M Huberman, 1992, Analisis Data Kualitatif, diterjemahkan T.R.Rohidi, UI Pers, Jakarta

15. Moekijat. 1991. Latihan dan Pengembangan Sumber Daya Manusia. Bandung: PT. Mandar Maju.

16. Nasution, S, 1988, Metode Penelitian Naturalistik - Kualitatif, Tarsito, Bandung

17. Nitisemo, Alex. S, 2008, Manajemen Personalia (Manajemen Sumber Daya Manusia), Ghalia Indonesia, Jakarta.

18. Notoadmodjo, soekidjo. 1998. Pengembangan Sumber Daya Aparatur. Rineka Cipta. Jakarta.

19. Siagian, Sondang P. 1999. Manajemen Sumber Daya Manusia. Cetakan Ketujuh. Bumi Aksara. Jakarta.

20. Simamora, Henry, 2006, Manajemen Sumber Daya Manusia, edisi ketiga, cetakan kedua, penerbit : YKPN, Yogyakarta.

21. Tayibnapis, Burhanuddin.A, 1995, Administrasi Kepegawaian, Pradinja Paramita, Jakarta

22. Werther, Jr, William B and Keith Davis. 1989. Human resources and Personnel Management, International Edition, McGraw-Hill Book Company, Singapore. 